Article

\title{
Risk and Culture of Health Portrayal in a U.S. Cross-Cultural TV Adaptation, a Pilot Study
}

\author{
Darien Perez Ryan * and Patrick E. Jamieson \\ Annenberg Public Policy Center, University of Pennsylvania, Philadelphia, PA 19104, USA; \\ E-Mails: darien.ryan@appc.upenn.edu (D.P.R), patrick.jamieson@appc.upenn.edu (P.E.J.) \\ * Corresponding author
}

Submitted: 22 March 2018 | Accepted: 17 September 2018 | Published: 5 February 2019

\begin{abstract}
Because media portrayal can influence adolescents' health, we assessed the health-related content of a popular telenovela-a Spanish-language TV soap opera genre-and its widely watched English adaptation. To test our "culture of corruption" hypothesis, which predicts that the English-language adaptation of telenovelas will "Americanize" their content by increasing risky and reducing healthy portrayal on screen, we coded the depictions of five risk variables and five culture of health ones in ten episodes each of "Juana la Virgen" (2002) and its popular English-language counterpart, "Jane the Virgin" (2014). A significant increase was found between the Spanish and English-language shows in the risk category of sexual content and a marginally significant increase was found in violence. "Jane" also had larger numbers of characters modeling alcohol consumption, sex, or violence. Across culture of health variables, "Juana" and "Jane" did not exhibit significant differences in the amounts of education-related content, social cohesion, and exercise at the episode level. However, "Jane" had significantly more unhealthy food content (specifically, fats, oils, and sweets and takeout food) and more pro-health messaging than did "Juana." "Jane" also had a larger amount of modeled food/beverage consumption. While "Juana" modeled several instances of characters involved in exercise, "Jane" had no exercise content across the sample. Overall, "Jane" portrayed more problematic health content than "Juana." The increase in worrisome content in "Jane" may adversely affect the health of adolescent Hispanics, who make up a large part of the show's audience.
\end{abstract}

\section{Keywords}

adolescent; content analysis; health; Hispanic; media; risk; telenovela; television

Issue

This article is part of the issue "Communicating on/with Minorities", edited by Leen d'Haenens and Willem Joris (KU Leuven, Belgium).

(C) 2019 by the authors; licensee Cogitatio (Lisbon, Portugal). This article is licensed under a Creative Commons Attribution 4.0 International License (CC BY).

\section{Introduction}

Media exposure in the United States remains high, particularly among U.S. adolescents who consume up to nine hours a day of screen-based media (Lauricella et al., 2016). Despite the increasing use of smartphones, tablets, and other digital platforms, television remains popular with U.S. audiences, who watched an average of five hours of television per day in 2016 (Nielsen, 2016). The U.S. Hispanic population has become a highly coveted demographic for the television industry. Not only has the U.S. Hispanic population increased six-fold since the early 1970s, but its expansion accounted for more than half of the country's population growth between 2000 and 2014 (Krogstad, 2016).

The majority of Hispanic television viewing is made up of telenovelas-a Spanish-language TV soap opera genre widely viewed across Latin America, as well as in the U.S. where Hispanics watch them on major Spanish-language television networks like Univision and Telemundo. A 2016 Federal Communication Commission (FCC) study concluded that Hispanic viewers in the U.S. watched more telenovelas than any other programming (Office of Strategic Planning and Policy Analysis, 2016). Viewership of such programs has surged both across audience age groups and within the demographic 
most valued by advertisers, 18-34 year olds (Jacobson, 2012). Notably, U.S. networks are beginning to target the "billennial" audience-millennials who grow up speaking and consuming media in both English and Spanish, a demographic with growing purchasing power (Villarreal, 2015).

Major U.S. television networks began to see marketing potential in adapting the already-popular telenovela format following the success of $A B C$ network's "Ugly Betty" (2006). That adaptation of the hit Colombian telenovela "Yo Soy Betty, la Fea" (1999) was the first TV migration of a narrative from a Spanish-language program into a major English-language show. While a few short-lived attempts at telenovela adaptations occurred after the four-season run of "Ugly Betty", it was not until the premiere of "Jane the Virgin" in October 2014 on the CW network that a U.S. network once again found commercial success in adapting a telenovela storyline for a U.S. audience. "Jane the Virgin" is an adaptation of "Juana la Virgen", a 2002 telenovela series that enjoyed a highly rated run both in Venezuela on Radio Caracas Televisión and on Univision in the United States. The premiere of "Jane the Virgin" reached an audience of 1.6 million (Bibel, 2014) and the series averaged 1.2 million total viewers across its first season. To date, "Jane" not only has run for four seasons, with a fifth and final season slated to air in 2019, but has also received numerous accolades including a Golden Globe win for actress Gina Rodriguez in the role of Jane Villanueva.

TV adaptations from one culture to another, such as "Jane the Virgin", are of particular interest because they undergo "textual changes to fit in with the prevailing values, preferences, viewing habits, and local sensibilities of the adapting culture" (Joye, Biltereyst, \& Adriaens, 2017, p. 356). The process of adapting telenovelas for foreign markets is most successful when the programs have relatable global archetypes and elements in the narrative that can be localized, ultimately allowing the narrative to fit within the social fabrics of the new media landscapes they enter (Miller, 2010). In the case of "Jane the Virgin", media flow South-to-North culturally (Miller, 2010) lends itself to potentially problematic changes, as the narrative structure transforms in order to meet American media norms.

Studies have found that the amount of portrayed risk in American media, such as television and movies, has increased in recent decades, specifically in the categories of violence (American Academy of Pediatrics, 2009), gun violence (Bushman, Jamieson, Weitz, \& Romer, 2013), sex (Kunkel, Eyal, Finnerty, Biely, \& Donnerstein, 2005), and alcohol use (Breed \& De Foe, 1981; Russell \& Russell, 2009). Adaptations, such as "Jane the Virgin", which cross into American mainstream media could be influenced by what we refer to as a "culture of corruption", as they interact and respond to a media landscape that features increasingly problematic content. According to uses and gratifications theory, TV audiences may be exposed to, demand more of, and subsequently watch riskier content (Rubin, 2009). Indeed, media audience members generate expectations of mass media and, in turn, engage in the selection of media to satisfy needs or desires (Katz, Blumler, \& Gurevitch, 1973). This "audience self-selection" not only affects the types of content media producers choose to create, but also ultimately manifests itself in behavioral responses to the portrayed content that filter through relationships, personality, and social interaction. If audiences select, accommodate, seek out, and view more of such content, this theory would predict that problematic content would increase over time. Accordingly, in order to make the show marketable and increase audience share, "Jane the Virgin" would be expected to undergo narrative changes to fit the current societal standards for American media content.

Higher levels of problematic content on screen are also cause for concern because, as Bandura's (2009) social cognitive theory of mass communication (SCTMC) suggests, after a media-portrayed act is observed and coded into memory by an audience member, it can be recalled and transformed into a re-enacted action or behavior. Meta-analyses have found that behavioral outcomes are affected by risk-taking behaviors portrayed on screen (Fischer, Greitemeyer, Kastenmüller, Vogrincic, \& Sauer, 2011). The media portrayal of alcohol (Dal Cin, Worth, Dalton, \& Sargent, 2008; Hanewinkel et al., 2014), sex (Hennessy, Bleakley, Fishbein, \& Jordan, 2009), and violence (Bushman \& Huesmann, 2006) have been found to predict corresponding problematic health behaviors.

Cultivation theory (Gerbner, Gross, Morgan, Signorielli, \& Shanahan, 2009) posits that when individuals are exposed to a consistent set of messages on television, they integrate these messages into their perception of reality. Consequently, "culture of health" content modeled on primetime television may affect perceptions and behaviors involving issues such as healthy eating or receiving medical treatment. For example, Signorielli and Lears (1992) found that television viewing, including exposure to food and beverages embedded in show narratives, was a strong predictor of poor nutritional eating habits as well as misconceptions about what constitutes a healthy meal for adolescents.

The importance of cultivation of health-related messages on television (Lee \& Niederdeppe, 2011) is magnified by the finding that Hispanic audience members often rely on media-based health and medical information. Although $71 \%$ of Hispanics reported that in the past year they had obtained health information from a doctor, with a similar percentage receiving information from sources such as family, friends, and churches, $83 \%$ were found to have gained health information from media sources, predominantly television. Furthermore, $79 \%$ reported acting on media-based health information (Livingston, Minushkin, \& D'Vera, 2008). As a result, telenovelas have become a stage for educationentertainment initiatives, including health-related storylines illustrating the importance of actions such as rou- 
tine cancer and STD screenings. Such narratives can increase health knowledge and behavioral intent in their audiences (Forster, Allem, Mendez, Qazi, \& Ungar, 2016; Wilkin et al., 2007). The quality and frequency of mediabased health modeling is of importance as well because it may explain why Hispanics who have lived in the U.S. for some time are more at-risk for medical problems including obesity and heart disease (Dominguez et al., 2015) than are newly-immigrated Hispanics.

The potential contribution of a "culture of corruption" to higher levels of problematic content on television is worrisome, especially for at-risk adolescent Hispanics. Young Hispanic viewers make up a significant portion of the audience for "Jane the Virgin". The first season of "Jane the Virgin" had about twice the rate of Hispanic viewers in the 12-18 age category as the composite audience (Nielsen, 2015). Concern is warranted especially for adolescent female Hispanic TV-watchers who may identify with the study sample's adolescent female Hispanic protagonists, Jane and/or Juana. Young adults can engage in wishful identification with fictional television characters, especially those who are similar in gender and attitudes (Hoffner \& Buchanan, 2005).

The susceptibility of Hispanic TV watchers to media's problematic modeled content may be magnified by the fact that Hispanics are more likely to binge watch TV. In a recent study, the majority of Hispanics (60\%) reported that they had watched the entire season of a TV show during a single weekend compared with $49 \%$ of non-Hispanics (Carrasco, 2015). Importantly, the serial nature of telenovelas, which often air daily and frequently contain more than one hundred episodes, could combine with binge watching to heighten problematic effects from media modeling.

Research on telenovela adaptations has been limited, in part because the number of these adapted crosscultural shows so far is still small, especially in the United States. Studies have focused primarily on international adaptations of "Yo Soy Betty, la Fea" (McCabe \& Akass, 2013) with attention to aesthetic differences (Mikos \& Perrotta, 2012), the portrayal of specific national identities in those adaptations (Adriaens \& Biltereyst, 2011), the telenovela as a glocalized product (Joye et al., 2017), and how industrial logics govern the circulation of telenovelas in the English-language market (Conway, 2012). The importation of themes from Spanish telenovelas into U.S. television has been studied (Bielby \& Harrington, 2005), as has how telenovela content is linked with cultural identity (Merayo, 2013; Pérez, 2005), and the production and reception of sociocultural issues in telenovelas (Acosta-Alzuru, 2010). Research has also been conducted on U.S. prime-time programming for the frequency and quality of depictions of Latinos (Hoffman \& Noriega, 2004; Mastro \& Behm-Morawitz, 2005; MonkTurner, Heiserman, Johnson, Cotton \& Jackson, 2010).

This pilot study aims to make a novel contribution to the literature by hypothesizing and testing whether the process of adaptation into American mainstream media is associated with more problematic health-related content in "Jane the Virgin" than in the show from which it was originally adapted, "Juana la Virgen".

\section{Method}

\subsection{Sample}

The CHAMPION (Culture of Health and Media Project in Our Nation) content analysis project codes risk and culture of health variables in popular TV shows, including dramas, sitcoms, and telenovelas. From this latter category, ten episodes were sampled for this pilot comparison of "Jane the Virgin" and "Juana la Virgen". Eight of these episodes were randomly selected across the 2002 airing of "Juana" and eight from the first season (2014-2015) of "Jane" (the only season available at the time of coding), with the first and last episode of each coded as well, for a total of 15 commercial-free hours of TV programming.

\subsubsection{Coding}

Four coders participated in this study and were blind to the study's hypotheses. TV episodes were unitized into and then coded as 5-minute segments (i.e., a 40-minute long episode was coded as 8 segments). All four coders were trained on about 11.3 hours of content covering risk variables. The coders then completed a separate training on culture of health variables, consisting of about 10.5 hours of content. All coders met a Krippendorff's $\alpha \geq .80$ for all reported study variables (Krippendorff, 2018). In order to account for the cross-language application of the study definitions (as some study variables capture verbal as well as visual content), after completing the English-language training, a subset of coders with native fluency in English and Spanish completed additional training on Spanish-language TV content for risk and culture of health variables, for a total of about 8 more hours of training. These coders also met a Krippendorff's $\alpha \geq .80$ on all reported study variables. All materials used to train coders were comparable to the study content and not included in the study's TV sample.

\subsubsection{Measures}

When a risk or culture of health variable was evaluated for each TV episode 5-minute segment, a code of 0 vs. 1 was recorded to indicate "any such content" present in the segment, including verbal references for some coded categories. In an effort to determine the number of characters participating in modeling a behavior (implied or shown), instances were captured for the risk categories of alcohol, drugs, sex, and violence; for culture of health variables, the coders counted instances of consumption of food and beverage as well as participation in exercise. Instances were not captured for the categories of social cohesion, education, and pro-health messaging, as 
these measures were not easily quantifiable by participant behavior and instead were captured at the 5-minute segment level as "presence of" variables. Number of instances were also coded for each portrayal per character and summed per 5-minute segment. For example, drinking a soda and then opening a second can would count as two instances. When a character simultaneously or concurrently engaged in multiple behaviors, each was counted separately (e.g., punching a character and then using a gun to wound him would count as two separate instances). A distinct interruption of scenic location or timeframe for study content within the 5-minute segment (e.g., the same character drinking at a bar and then drinking later at home) was counted as two instances in that segment. Instances for the study variables were summed for each 5-minute segment per show. T-tests were conducted for variables with "any such content" at the 5-minute segment level. Instances were described as sums and in figures.

\subsection{Risk Variable Definitions}

\subsubsection{Alcohol}

Alcohol use was defined as direct or implied consumption of alcohol by a character in a 5-minute segment and also captured verbal references to drinking. A Krippendorff's alpha $(K \alpha) \geq .80$ was achieved for any such content. Alcohol instances per show had an $\alpha$ reliability $\geq .83$.

\subsubsection{Drugs}

Drug use included verbal references to drugs and was defined as direct or implied consumption of a drug or drugrelated product. Direct consumption included characters injecting, smoking, inhaling, or snorting a drug. Indirect consumption was coded when a character was involved with or preparing drugs, for example prepping a syringe. Types of drugs coded for included marijuana, cocaine, heroin, ecstasy, acid, opiates, and inhalants. A $\mathrm{K} \alpha \geq .81$ was met for any such drug. Drug instances per show was $\mathrm{K} \alpha \geq .80$.

\subsubsection{Sexual Content}

Sexual content was defined as explicit nudity or behaviors such as kissing, groping, fondling, or implied or explicit sexual intercourse. $\mathrm{K} \alpha$ for any such content $\geq .81$. Sex instances per show had an $\alpha$ reliability $\geq .82$. When sexual content was present, a subcategory variable captured whether intercourse was portrayed and if so, whether it was implied (i.e. characters waking up together in bed) or shown (simulated intercourse, with or without nudity). $\mathrm{K} \alpha$ for the intercourse subcategory was $\geq .86$.

\subsubsection{Violence}

Violent content was defined as "intentional acts where the aggressor makes or attempts to make some physical contact that has potential to inflict injury or harm" and was adapted from a previously published measure (Yokota \& Thompson, 2000). It excludes accidents and natural disasters. $K \alpha$ for any such content was $\geq .83$ and for violence instances was $\geq .82$.

\subsubsection{Gun Portrayal}

Gun portrayal was coded for any such content in a 5-minute segment and included situations in which a character brandishes a gun but does not fire it and scenes in which guns are visible in a non-use context, such as holstered or hanging on a wall, $\mathrm{K} \alpha \geq .80$.

\subsection{Culture of Health Variable Definitions}

\subsubsection{Food and Beverage}

Food and/or beverage consumption was defined as the direct or implied consumption of food or beverage by a character and was adapted from a previously published measure (Bell, Berger, Cassady, \& Townsend, 2005). Implied consumption was defined as characters not shown directly consuming food or drinking a beverage but involved with such content (i.e., holding a beverage but not seen sipping from it). $\mathrm{K} \alpha \geq .82$ was met for "any such food/beverage content". Instances of food and beverage consumption also met $\mathrm{K} \alpha$ reliability $\geq$.82. Subtypes of food captured included: grain, fruit, vegetables, protein, dairy, and fats/oils/sweets. For beverages, these categories included: water, milk, juice, soda, coffee/tea, or alcohol. Another category captured whether food/beverage was homemade as opposed to takeout/food purchased outside the home, $\mathrm{K} \alpha \geq .85$.

\subsubsection{Exercise}

Exercise was defined as direct or implied participation of a character in a physical activity with the shown, implied, or verbally stated purpose of fitness. $\mathrm{K} \alpha \geq .84$ was met for presence of any such content and $K \alpha$ reliability $\geq .87$ for instances of modeled behavior.

\subsubsection{Social Cohesion}

Social cohesion captured the portrayal of characters participating in activities which promote a shared identity specific to one of four categories. These included participation in: religious organizations/worship services or cultural practices, political organizations or community organizations, volunteer and charity organizations, and extracurricular groups including sports, $\mathrm{K} \alpha \geq .87$. 


\subsubsection{Education}

Educational content was operationalized as students shown in a classroom receiving instruction, students shown doing homework or studying, parents reading to children, or characters casually reading, $\mathrm{K} \alpha \geq .81$.

\subsubsection{Pro-Health Messaging}

The pro-health messaging category included situations in which characters were shown receiving care from a medical professional, encouraging others to seek medical advice, following medical advice/instructions, engaged in self-treatment for minor ailments, or seeking help for mental health or substance abuse problems, $\mathrm{K} \alpha \geq .91$.

\subsection{Data Analysis}

SPSS 24 was used to aggregate the study variables, was used for conducting statistics, and all statistical tests were two-tailed. Because the number of episode segments compared was the same, we did not control for the length of episodes. IRB approval was not sought because the study did not involve human subjects.

\section{Results}

Within the ten episode sample for each show, "Jane the Virgin" had 42 "any alcohol" 5-minute segments while "Juana la Virgen" had 45 segments. Total instances of alcohol consumption in "Jane" were 128 vs. 84 in "Juana" (Figure 1). "Jane" had 43 segments of "any sexual content" and "Juana" had 12. Instances of participation in sexual behaviors were 146 in "Jane" and 47 in "Juana" (Figure 1). Of the segments featuring sexual content, "Jane" had 11 segments with intercourse implied and 3 segments with intercourse shown, while "Juana" had 6 segments with implied intercourse and no segments of shown intercourse. In the segments which featured sexual content, no mention or portrayal of safe sex practices were noted within the random sample for either show. In the drug content category, "Jane" had 7 segments with "any such content" while "Juana" had 2. No instances of drug consumption were found for either show. For the violence category, "Jane" had 20 segments with violent content and "Juana" had 7 segments. Within the segments containing violent content, "Jane" had 17 instances of characters modeling violent behavior versus 8 in "Juana" (Figure 1). Gun portrayal was featured in 13 segments in "Jane" and in 6 segments for "Juana."

Paired-sample t-tests were conducted to compare the means of each of the five risk categories at the episode level between "Jane the Virgin" and "Juana la Virgen" to determine statistically significant differences (Table 1). Of the reported categories, a significant difference was found for sexual content (Mean $=-3.10,95 \% \mathrm{Cl}=(-4.47,-1.73), \mathrm{t}(9)=-5.13, \mathrm{p}=.001)$. Also, the between-show difference in violence was marginally significant (Mean $=-1.30,95 \% \mathrm{Cl}=(-2.73$, $0.13), t(9)=-2.05, p=.070)$. There were no significant differences between alcohol content, drug content, or gun portrayal (Table 1).

For culture of health variables, "Jane" had 78 fiveminute segments with any food or beverage content and "Juana" had 71. "Jane" had 77 instances of characters consuming food vs. 25 in "Juana" (Figure 2). For beverages, "Jane" featured 257 instances of beverage consumption while "Juana" had 121 instances (Figure 2). Of the food portrayed, "Jane" had 22 segments featuring unhealthy food content subcategories (specifically "fats, oils, and sweets") and "Juana" had a total of 11 segments with unhealthy food content. The adaptation "Jane" also featured 22 segments with takeout/restaurant food vs. 4 segments with such content in "Juana." Educational content was featured in 7 segments in "Jane" and 12 segments in "Juana." The random sample for "Jane" did not

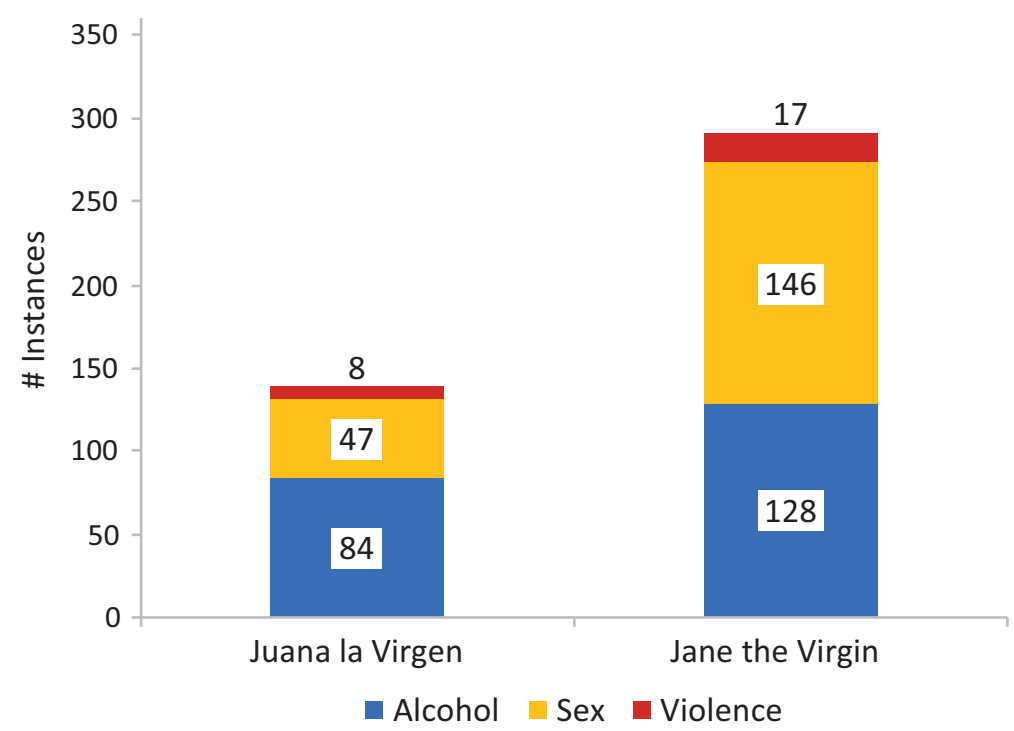

Figure 1. Risk variable instances summed per TV show. 
Table 1. Risk categories for "Jane the Virgin" v. "Juana la Virgen" (paired t-tests).

\begin{tabular}{|c|c|c|c|c|c|c|c|c|}
\hline \multirow[b]{2}{*}{ Risk variable } & \multirow[b]{2}{*}{ Mean } & \multirow[b]{2}{*}{ Std. deviation } & \multirow[b]{2}{*}{ Std. error mean } & \multicolumn{2}{|c|}{$\begin{array}{l}\text { 95\% confidence } \\
\text { interval of } \\
\text { difference }\end{array}$} & \multirow[b]{2}{*}{ p-value } & \multirow[b]{2}{*}{$t$} & \multirow[b]{2}{*}{ df } \\
\hline & & & & Lower & Upper & & & \\
\hline Alcohol content & .30 & 2.11 & .67 & -1.21 & 1.81 & .664 & .45 & 9 \\
\hline Sexual content & -3.10 & 1.91 & .61 & -4.47 & -1.73 & .001 & -5.13 & 9 \\
\hline Drug content & -.50 & .97 & .31 & -1.20 & .20 & .138 & -1.63 & 9 \\
\hline Violence & -1.30 & 2.00 & .63 & -2.73 & .13 & .070 & -2.05 & 9 \\
\hline Gun portrayal & -.70 & 1.64 & .52 & -1.87 & .47 & .209 & -1.35 & 9 \\
\hline
\end{tabular}

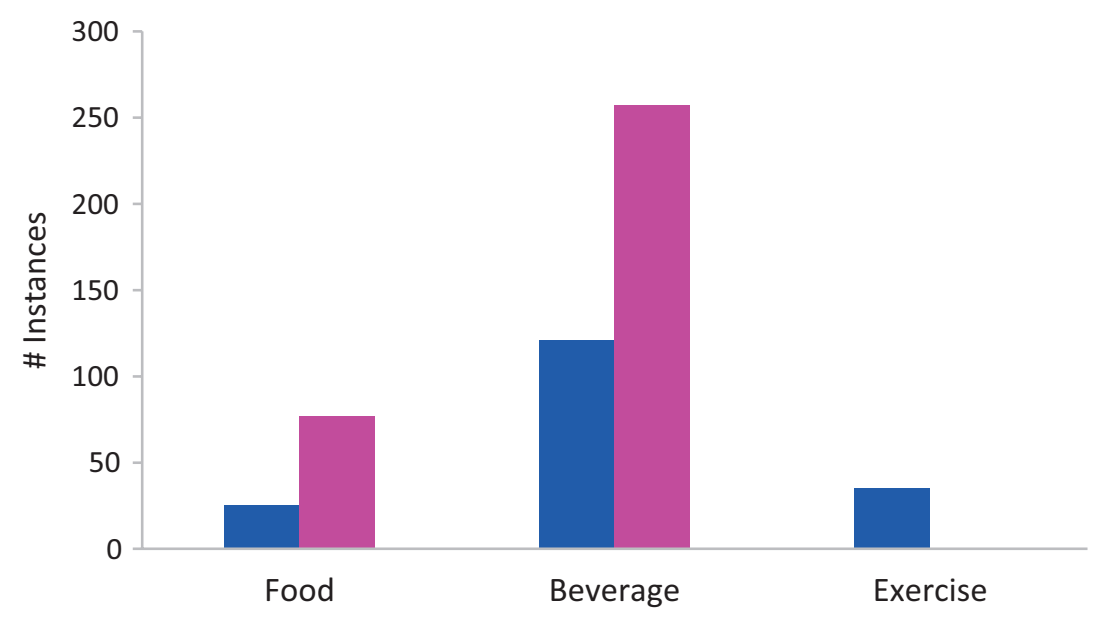

\section{Content Type}

- Juana la Virgen the Virgin

Figure 2. Culture of health variable instances summed per TV show.

Table 2. Culture of health categories for "Jane the Virgin" v. "Juana la Virgen" (paired t-tests).

\begin{tabular}{|c|c|c|c|c|c|c|c|c|}
\hline \multirow[b]{2}{*}{ Culture of health variable } & \multirow[b]{2}{*}{ Mean } & \multirow[b]{2}{*}{ Std. deviation } & \multirow[b]{2}{*}{ Std. error mean } & \multicolumn{2}{|c|}{$\begin{array}{l}\text { 95\% confidence } \\
\text { interval of } \\
\text { difference }\end{array}$} & \multirow[b]{2}{*}{ p-value } & \multirow[b]{2}{*}{$\mathbf{t}$} & \multirow[b]{2}{*}{ df } \\
\hline & & & & Lower & Upper & & & \\
\hline \multicolumn{9}{|l|}{ Food/beverage } \\
\hline Overall portrayal & -.10 & .34 & .11 & -.34 & .14 & .383 & -.92 & 9 \\
\hline Fats/oils/sweets & -.12 & .17 & .05 & -.24 & -.00 & .048 & -2.28 & 9 \\
\hline Takeout food & -.20 & .12 & .04 & -.28 & -.12 & .000 & -5.53 & 9 \\
\hline Exercise & .08 & .14 & .04 & -.02 & .18 & .112 & 1.77 & 9 \\
\hline Social cohesion & .02 & .10 & .03 & -.05 & .09 & .660 & .66 & 9 \\
\hline Education & .05 & .13 & .04 & -.04 & .15 & .220 & 1.32 & 9 \\
\hline Pro-health messaging & -.17 & .23 & .07 & -.33 & -.01 & .043 & -2.35 & 9 \\
\hline
\end{tabular}

include any segments with exercise. "Juana," however, had 7 segments featuring exercise content and a total of 35 instances of characters modeling exercise on screen (Figure 2). A nominal number of segments was found containing social cohesion content for both shows: 2 segments in "Jane" and 4 segments in "Juana." Pro-health messaging was present in 25 segments in "Jane" and in 10 segments for "Juana".

Paired sample t-tests were also conducted on culture of health category variables between shows (Table 2). "Jane" had significantly more fats/oils/sweets as a food subtype than "Juana" (Mean $=-.12,95 \% \mathrm{Cl}=(-.24$, 
$-.00), \mathrm{t}(9)=-2.28, \mathrm{p}=.048$ ) as well as more takeout/meals prepared outside the home (Mean $=-.20$, $95 \% \mathrm{Cl}=(-.28,-.12), \mathrm{t}(9)=-5.53, \mathrm{p}=000)$. The amount of pro-health messaging depicted for "Jane" was significantly more than for "Juana" (Mean $=-.17$, $95 \% \mathrm{Cl}=(-.33,-.01), \mathrm{t}(9)=-2.35, \mathrm{p}=.043)$. No statistically significant differences were found between shows for exercise, social cohesion, or education (Table 2).

\section{Discussion}

"Jane the Virgin" had significantly more 5-minute segments with sexual content and marginally more violence than "Juana la Virgen" (Table 1). "Jane" also had more total instances of characters modeling alcohol consumption, sex, and violent behavior (Figure 1). Across several of the culture of health variables, "Jane" and "Juana" had amounts of content that were not statistically significant in their differences (education, social cohesion, and exercise) with the exception of pro-health messaging and the negative "culture of health" food subcategories fats/oils/sweets and takeout food (Table 2). "Jane" exceeded "Juana" in total instances of characters consuming any food or beverage. "Juana" had 35 instances of characters modeling exercise while "Jane" did not portray any exercise content (Figure 2). Hence, "Jane the Virgin" had more negative health content overall than "Juana la Virgen". The difference in problematic content in "Jane the Virgin" could indicate the influence of American audience expectations on the narrative. Adapting a show, like "Jane the Virgin", to fit within a media landscape that is already saturated with increasingly problematic portrayals may ultimately lead to negative health consequences for the at-risk populations viewing such content, leading to reenactment of risky behaviors such as alcohol consumption, drug use, sex, and violence or other negative culture of health behaviors such as unhealthy eating. However, if TV shows model more positive behaviors such as promoting social cohesion and prosocial interactions (Mares \& Woodard, 2005), or reinforce the importance of education or healthcare (Brodie et al., 2001), these positive behaviors and attitudes could also be cultivated in TV audiences.

Plot and character changes that occurred during the process of cross-cultural adaptation may explain why more risk and fewer positive culture of health portrayals exist on screen in "Jane the Virgin" than in the original telenovela "Juana la Virgen." In order to complement the study's analysis of health content per 5-minute segment, these changes are explained at the narrative level. Both programs share a similar overarching plot-a religious, sexually inexperienced young woman is accidentally artificially inseminated as a result of a mistake by a gynecologist during a doctor's appointment. However, Juana and Jane, the main protagonists in the telenovela and its adaptation, differ significantly in their on-screen portrayal. Juana Perez is a 17-year-old academically accomplished high school student and the star of her high school's soccer team. As a result, Juana's character and situation in the Spanish-language telenovela are more suited to depictions of education (as Juana is seen frequently at her school), as well as exercise and social cohesion as a result of Juana practicing for and competing in soccer matches with her team. Juana's mother, Ana Maria, is a physical education teacher at the high school as well, a factor that opens the plot to more frequent portrayal of exercise and education. This is evident in the study's sample, which featured 35 instances of characters modeling exercise in "Juana" while "Jane" included no such content. This is consistent with the "culture of corruption" hypothesis, which would predict less positive health content in the later TV adaptation as a result of the narrative migration.

In contrast, Jane is a 24-year-old college student studying English and aspiring to be a romance novelist. Not only does her character's older age makes it appropriate for her to drink and serve alcohol, but Jane is also featured working part-time as a waitress at the Marbella to pay her way through college. The Marbella, a ritzy Miami hotel known for its lavish large-scale parties, becomes a central fixture for the show. Jane frequently works these parties, which feature large amounts of alcohol consumption on screen. As the primary backdrop for the show, Jane's presence at the Marbella also likely led to the disparity between the telenovela and the adaptation in portrayal of unhealthy eating, because much of the food consumed on screen is from the hotel restaurant.

The English-language adaptation also introduces into the plot a boyfriend for Jane-Michael Cordero-who is a gun-carrying Miami police detective and involved in investigating a drug ring and several murders that take place at the Marbella. These plot changes entailed higher levels of risky content on screen, particularly in the categories of sexual content, drugs, and violence related to the crime narrative. In contrast, Juana abstains in the original program from romantic relationships of any sort in order to keep herself from being distracted from her goal of receiving a scholarship to study photography in the United States.

Variations between the two stories may also account for differences in the pro-health messaging content between "Jane" and "Juana." Specifically, the two programs approach the unexpected pregnancy narrative in different ways. When Juana discovers that she has accidentally become pregnant, she attempts to hide it from her family and friends. Indeed, to avoid the social stigma associated with teen pregnancy, she even flees from her home. Thus, Juana is not shown receiving regular medical care for her pregnancy, a fact that decreased the likelihood of pro-health messaging on screen. In contrast, Jane finds out about her pregnancy with her mother present. Rather than hiding her pregnancy from others, she actively seeks the support of her family and the child's father and is shown regularly attending doctor appointments and following prenatal advice. These exam- 
ples make it evident that risk and culture of health content on screen can be increased or decreased depending on the deliberate choices made when changing the narrative structure or character profiles in a show adaptation.

It is important to consider the potential effects of the heightened problematic content in "Jane the Virgin" on the Hispanic adolescent population, which is a majority of the show's audience. Television programming that depicts alcohol consumption may promote an increase in drinking by the target audience; (Dal Cin et al., 2008; Hanewinkel et al., 2014). While Hispanics are less likely to drink alcohol than are non-Hispanic whites, Hispanics who do engage in drinking are more likely to consume more alcohol than other demographic groups (National Institute on Alcohol Abuse and Alcoholism, 2015). Importantly, the National Institute on Alcohol Abuse and Alcoholism recognizes acculturation as a major factor in predicting drinking patterns in the U.S. Hispanic community (NIAAA, 2015); this acculturation includes exposure to Americanized media. In light of recent research indicating that the safest level of alcohol consumption is no consumption (GBD 2016 Alcohol Collaborators, 2018), concern is warranted especially when a show, such as "Jane the Virgin", models significant instances of characters drinking on screen, even within a ten episode sample. While arguably Jane's character is of appropriate age and can be shown both consuming and handling alcohol, modeling alcohol use to the adolescents who make up the audience of the show may promote underage drinking, an undesirable outcome.

The show "Jane the Virgin", which models three times the amount of character engagement in sexual content than its originating program, also may promote adolescent audience engagement in similar behavior without mitigating these risks by depicting the use of safe sex practices. TV portrayal also predicts sexual-related health (Hennessy et al., 2009). Adolescents who view more sexual content on television have been shown to be more likely to progress in the participation of non-coital activities and to have sex earlier (Collins et al., 2004). Moreover, exposure to television programming that only talks about or mentions sex and sexual activities as opposed to showing intercourse actively on screen is associated with the same risks (Collins et al., 2004). Sexually transmitted diseases and unplanned pregnancies are also more common among individuals who begin sexual activity early (Koyle, Jensen, Olsen, \& Cundick, 1989). Sexually transmitted infections are prevalent among adolescents ages 15-24 and account for half of almost 20 million annual infections (Centers for Disease Control and Prevention [CDC], 2016). In 2014 alone, U.S. Hispanics averaged almost two times the rates of gonorrhea, chlamydia, and syphilis cases as non-Hispanic whites. And while Hispanics make up around $17 \%$ of the U.S. population, they accounted for about 23\% of HIV diagnoses in 2014 (CDC, 2014).

Violent content and gun portrayal in "Jane the Virgin" may also promote acceptance of violence and predict reenactments of such behaviors (Bushman \& Huesmann, 2006). This is important because violence continues to be a major public health problem for U.S. Hispanics in general and Hispanic adolescents in particular. Despite indications of a decline in overall violent crimes in the United States (Federal Bureau of Investigation, 2017), between 1999 and 2015, nearly 54,000 Hispanics were killed by guns, with 3,300 Hispanic victims of gun violence in 2015 alone (Violence Policy Center, 2018). Of these, $66 \%$ were homicide-related and the rates of Hispanic homicide victimization were almost double that of nonHispanic whites. Importantly, homicide is the second leading cause of death for Hispanics age 15-24 (Violence Policy Center, 2018). A media landscape with frequently portrayed violent content may be detrimental to at-risk youth viewers. The well-documented weapons effect (Anderson, Benjamin Jr., \& Bartholow, 1998; Berkowitz \& LePage, 1967; Leyens \& Parke, 1975) indicates that the mere presence of guns, whether in use or non-use settings, can increase aggression in audiences. Hence, care should be taken to reduce the amount of gun portrayal on television, both in "Jane the Virgin" and in other shows targeting youths and Hispanic adolescents specifically, given their population's already-elevated risk of victimization from violence.

Because Hispanic adolescents are at an elevated risk for obesity, the role and frequency of unhealthy eating content in "Jane" is of concern as well. According to the CDC (2017a), the prevalence of childhood and adolescent obesity is higher among Hispanics than among nonHispanic whites (21.9\% vs. $14.7 \%$ ). This is important because of the link between being overweight and developing diabetes. An estimated 30.3 million people across all ages in the U.S. have diabetes. From 2011-2014, diagnosed and undiagnosed diabetes cases were higher among U.S. minority groups, particularly Hispanics, compared with non-Hispanic whites (CDC, 2017b).

Despite this increased problematic content, there may be positive effects on the audience from the increased pro-health messaging depicted on screen in "Jane the Virgin". This includes scenes modeling regularly attending doctor's appointments, following medical instruction and advice (especially as related to pregnancy), and seeking support from social networks to deal with health consequences. Ultimately, producers of television programming should be informed that adolescents in general, including adolescent Hispanics, may be negatively affected by increases in the portrayal of negative health content on shows such as "Jane the Virgin", achieved through both plot devices and set design choices. Conscious helpful decisions can be made when preparing a narrative for adaptation to decrease the amount of negative health content on screen and increase positive and healthy depictions.

This pilot study has strengths and limitations. A strength is that it evaluated a novel popular sample and coded it with high reliability (i.e., $\mathrm{K} \alpha \geq .80$ ) for both risk and culture of health content in Spanish and in English. 
Its limitations include having a necessarily small sample, 20 total TV episodes (a byproduct of availability at the time of coding), and only drawing from a single genretelenovelas. Future research should quantitatively test the study hypothesis using larger sample sizes. Whether such results from one telenovela adaptation can be replicated and generalized across other TV adaptations and genres could also be determined. Controlling for age, gender, education, racial-ethnic-identity, SES, various political attitudes, and the use of multiple media, including social media such as YouTube.com, Facebook, and Twitter is important. Future research could also determine how such TV exposure may help or harm the longterm health of at-risk adolescent Hispanic audiences.

In conclusion, although there were some positive health portrayals in "Jane the Virgin", this study found more problematic health content in the program than in the original telenovela from which it was adapted. The findings provide some initial support for our proposed "culture of corruption" hypothesis, which posits that the "Americanization" of the Spanish-language telenovela may result in increased media portrayal of problematic content, which could in turn adversely affect its adolescent Hispanic audiences.

\section{Acknowledgements}

The authors thank the Annenberg Public Policy Center (APPC) and the Robert Wood Johnson Foundation's (RWJF) Culture of Health $(\mathrm{CoH})$ initiative for their financial support of the CHAMPION project. The CHAMPION coders are thanked: Juan Cabrera, Mia Leyland, Rachel MacDonald, and Salomon Villatoro.

\section{Conflicts of interest}

The authors declare no conflict of interests.

\section{References}

Acosta-Alzuru, C. (2010). Beauty queens, machistas and street children: The production and reception of socio-cultural issues in telenovelas. International Journal of Cultural Studies, 13(2), 185-203. doi:10.1177/1367877909356719

Adriaens, F., \& Biltereyst, D. (2011). Glocalized telenovelas and national identities: A "textual cum production" analysis of the "telenovelle" Sara, the Flemish adaptation of "Yo Soy Betty, la Fea". Television \& New Media, 13(6), 551-567. doi:10.1177/ 1527476411427926

American Academy of Pediatrics. (2009). Policy statement-Media violence. Pediatrics, 124(5), 1495-1503. doi:10.1542/peds.2009-2146

Anderson, C. A., Benjamin Jr., A. J., \& Bartholow, B. D. (1998). Does the gun pull the trigger? Automatic priming effects of weapon pictures and weapon names. Psychological Science, 9(4), 308-314. doi:10.1111/1467-9280.00061

Bandura, A. (2009). Social cognitive theory of mass communication. In J. Bryant \& M. B. Oliver (Eds.), Media effects: Advances in theory and research (3rd ed., pp. 94-124). New York, NY: Routledge.

Bell, R. A., Berger, C. R., Cassady, D., \& Townsend, M. S. (2005). Portrayals of food practices and exercise behavior in popular American films. Journal of Nutrition Education and Behavior, 37(1), 27-32. doi:10.1016/ S1499-4046(06)60256-X

Berkowitz, L., \& LePage, A. (1967). Weapons as aggression-eliciting stimuli. Journal of Personality and Social Psychology, 7(2), 202-207. doi:10.1037/ h0025008

Bibel, S. (2014). Monday final ratings: 'The voice' \& 'Dancing with the stars' adjusted up; 'The big bang theory' \& 'Castle' adjusted down. TV by the Numbers. Retrieved from http://tvbythenumbers.zap2it. com/2014/10/14/monday-final-ratings-the-voice-the -big-bang-theory-castle-adjusted-down/314463

Bielby, D. D., \& Harrington, C. L. (2005). Opening America? The telenovela-ization of US soap operas. Television \& New Media, 6(4), 383-399. doi:10.1177/ 1527476405279861

Breed, W., \& De Foe, J. R. (1981). The portrayal of the drinking process on prime-time television. Journal of Communication, 31(1), 58-67. doi:10.1111/j.14602466.1981.tb01205.x

Brodie, M., Foehr, U., Rideout, V., Baer, N., Miller, C., Flournoy, R., \& Altman, D. (2001). Communicating health information through the entertainment media. Health Affairs, 20(1), 192-199. doi:10.1377/ hlthaff.20.1.192

Bushman, B. J., \& Huesmann, L. R. (2006). Short-term and long-term effects of violent media on aggression in children and adults. Archives of Pediatrics \& Adolescent Medicine, 160(4), 348-352. doi:10.1001/ archpedi.160.4.348

Bushman, B. J., Jamieson, P. E., Weitz, I., \& Romer, D. (2013). Gun violence trends in movies. Pediatrics, 132(6), 1014-1018. doi:10.1542/peds.2013-1600

Carrasco, M. X. (2015). TV binge viewing habits of Hispanic consumers. ThinkNow Research. Retrieved from http://www.thinknowresearch.com/blog/tvbinge-viewing-habits-of-hispanic-consumers

Centers for Disease Control and Prevention. (2014). Hispanic/Latinos: Health disparities in HIV/AIDS, viral hepatitis, STDS, and TB. Retrieved from https:// www.cdc.gov/nchhstp/healthdisparities/hispanics. html

Centers for Disease Control and Prevention. (2016). 2016 STD prevention conference highlights. Retrieved from https://www.cdc.gov/stdconference/ 2016/highlights/adol.htm

Centers for Disease Control and Prevention. (2017a). Childhood obesity facts. Retrieved from https://www.cdc.gov/obesity/data/childhood.html

Centers for Disease Control and Prevention. (2017b). 
National diabetes statistics report 2017: Estimates of diabetes and its burden in the United States. Retrieved from http://www.diabetes.org/assets/ pdfs/basics/cdc-statistics-report-2017.pdf

Collins, R. L., Elliott, M. N., Berry, S. H., Kanouse, D. E., Kunkel, D., Hunter, S. B., \& Miu, A. (2004). Watching sex on television predicts adolescent initiation of sexual behavior. Pediatrics, 114(3), 280-289. doi:10.1542/peds.2003-1065-L

Conway, K. (2012). Cultural translation, global television studies, and the circulation of telenovelas in the United States. International Journal of Cultural Studies, 15(6), 583-598. doi:10.1177/ 1367877911422291

Dal Cin, S., Worth, K. A., Dalton, M. A., \& Sargent, J. D. (2008). Youth exposure to alcohol use and brand appearances in popular contemporary movies. Addiction, 103(12), 1925-1932. doi:10.1111/j.13600443.2008.02304.x

Dominguez, K., Penman-Aguilar, A., Chang, M. H., Moonesinghe, R., Castellanos, T., Rodriguez-Lainz, A., \& Schieber, R. (2015). Vital signs: Leading causes of death, prevalence of diseases and risk factors, and use of health services among Hispanics in the United States-2009-2013. Morbidity and Mortality Weekly Report, 64(17), 469-478. Retrieved from https://www.cdc.gov/mmwr/preview/mmwrhtml/ mm6417a5.htm

Federal Bureau of Investigation. (2017). Uniform crime reporting statistics, 1960-2014. Retrieved from https://www.ucrdatatool.gov/Search/Crime/State/ RunCrimeStatebyState.cfm

Fischer, P., Greitemeyer, T., Kastenmüller, A., Vogrincic, C., \& Sauer, A. (2011). The effects of risk-glorifying media exposure on risk-positive cognitions, emotions, and behaviors: A meta-analytic review. Psychological Bulletin, 137(3), 367-390. doi:10.1037/ a0022267

Forster, M., Allem, J. P., Mendez, N., Qazi, Y., \& Unger, J. B. (2016). Evaluation of a telenovela designed to improve knowledge and behavioral intentions among Hispanic patients with end-stage renal disease in Southern California. Ethnicity \& Health, 21(1), 58-70. doi:10.1080/13557858.2015.1007119

Gerbner, G., Gross, L., Morgan, M., Signorielli, N., \& Shanahan, J. (2009). Growing up with television: Cultivation processes. In J. Bryant \& D. Zillman (Eds.), Media effects: Advances in theory and research (3rd ed., pp. 34-49). New York, NY: Routledge.

GBD 2016 Alcohol Collaborators. (2018). Alcohol use and burden for 195 countries and territories, 1990-2016: A systematic analysis for the Global Burden of Disease Study 2016. Lancet. doi:10.1016/S01406736(18)31310-2

Hanewinkel, R., Sargent, J. D., Hunt, K., Sweeting, H., Engels, R. C., Scholte, R. H., ... Morgenstern, M. (2014). Portrayal of alcohol consumption in movies and drinking initiation in low-risk adolescents. Pediatrics,
133(6), 973-982. doi:10.1542/peds.2013-3880

Hennessy, M., Bleakley, A., Fishbein, M., \& Jordan, A. (2009). Estimating the longitudinal association between adolescent sexual behavior and exposure to sexual media content. Journal of Sex Research, 46(6), 586-596. doi:10.1080/00224490902898736

Hoffman, A. R., \& Noriega, C. A. (2004). Looking for Latino regulars on prime-time television: The fall 2002 season. UCLA Chicano Studies Research Center. Retrieved from http://www.chicano.ucla.edu/ files/crr_04Dec2004_000.pdf

Hoffner, C., \& Buchanan, M. (2005). Young adults' wishful identification with television characters: The role of perceived similarity and character attributes. Media Psychology, 7(4), 325-351. doi:10.1207/ S1532785XMEP0704_2

Jacobson, R. (2012). The power of the telenovela. PBS Newshour Online. Retrieved from http://www.pbs. org/newshour/rundown/the-power-of-the-telenovela

Joye, S., Biltereyst, D., \& Adriaens, F. (2017). Telenovelas and/as adaptations: Reflections on local adaptations of global telenovelas. In T. Leitch (Ed.), The Oxford handbook of adaptation studies (pp. 356-369). New York, NY: Oxford University Press.

Katz, E., Blumler, J. G., \& Gurevitch, M. (1973). Uses and gratifications research. Public Opinion Quarterly, 37(4), 509-523. doi:10.1086/268109

Koyle, P. F., Jensen, L. C., Olsen, J., \& Cundick, B. (1989). Comparison of sexual behaviors among adolescents having an early, middle, and late first intercourse experience. Youth \& Society, 20(4), 461-476. doi:10.1177/0044118X89020004005

Krippendorff, K. (2018). Content analysis: An introduction to its methodology. (4th ed.). Thousand Oaks, CA: Sage Publications.

Krogstad, J.M. (2016). Key facts about how the U.S. Hispanic population is changing. Pew Research Center. Retrieved from http://www.pewresearch. org/fact-tank/2016/09/08/key-facts-about-how-theu-s-hispanic-population-is-changing

Kunkel, D., Eyal, K., Finnerty, K., Biely, E., \& Donnerstein, E. (2005). Sex on TV 4. Menlo Park: Kaiser Family Foundation.

Lauricella, A. R., Cingel, D. P., Beaudoin-Ryan, L., Robb, M. B., Saphir, M., \& Wartella, E. A. (2016). The common sense census: Plugged-in parents of tweens and teens. San Francisco, CA: Common Sense Media.

Lee, C. J., \& Niederdeppe, J. (2011). Genre-specific cultivation effects: Lagged associations between overall TV viewing, local TV news viewing, and fatalistic beliefs about cancer prevention. Communication Research, 38(6), 731-753. doi:10.1177/ 0093650210384990

Leyens, J. P., \& Parke, R. D. (1975). Aggressive slides can induce a weapons effect. European Journal of Social Psychology, 5(2), 229-236. doi:10.1002/ ejsp. 2420050207

Livingston, G., Minushkin, S., \& D’Vera, C. (2008). His- 
panics and health care in the United States: Access, information, and knowledge: a joint Pew Hispanic Center and Robert Wood Johnson Foundation research report. Pew Hispanic Center. Retrieved from http://www.pewhispanic.org/files/reports/91.pdf

Mares, M. L., \& Woodard, E. (2005). Positive effects of television on children's social interactions: A meta-analysis. Media Psychology, 7(3), 301-322. doi:10.1207/S1532785XMEP0703_4

Mastro, D. E., \& Behm-Morawitz, E. (2005). Latino representation on primetime television. Journalism \& Mass Communication Quarterly, 82(1), 110-130. doi:10.1177/107769900508200108

McCabe, J., \& Akass, K. (Eds.). (2013). TV's Betty goes global: From telenovela to international brand. New York, NY: IB Tauris.

Merayo, M. C. (2013). Telenovelas and society: Constructing and reinforcing the nation through television fiction. European Journal of Cultural Studies, 16(2), 211-225. doi:10.1177/1367549412467178

Mikos, L., \& Perrotta, M. (2012). Traveling style: Aesthetic differences and similarities in national adaptations of "Yo Soy Betty, la Fea". International Journal of Cultural Studies, 15(1), 81-97. doi:10.1177/ 1367877911428116

Miller, J. L. (2010). Ugly Betty goes global: Global networks of localized content in the telenovela industry. Global Media and Communication, 6(2), 198-217. doi:10.1177/1742766510373717

Monk-Turner, E., Heiserman, M., Johnson, C., Cotton, V., \& Jackson, M. (2010). The portrayal of racial minorities on primetime television: A replication of the Mastro and Greenberg study a decade later. Studies in Popular Culture, 32(2), 101-114. doi:10.2307/ 23416158

National Institute on Alcohol Abuse and Alcoholism. (2015). Alcohol and the Hispanic community. Retrieved from https://pubs.niaaa.nih.gov/publications /hispanicfact/hispanicfact.htm

Nielsen. (2015). Nielsen program ranking trend analysis unpublished report for season year 2014-2015. Prepared for CHAMPION project, New York, NY.
Nielsen. (2016). The Nielsen total audience report: Q1, 2016. Retrieved from http://www.nielsen.com/ content/dam/corporate/us/en/reports-downloads/ 2016-reports/total-audience-report-q1-2016.pdf

Office of Strategic Planning and Policy Analysis. (2016). Hispanic television media study. U.S. Federal Communications Commission. Retrieved from https:// apps.fcc.gov/edocs_public/attachmatch/DOC-33934 5A1.pdf

Pérez, M. D. (2005). Cultural identity: Between reality and fiction. A transformation of genre and roles in Mexican telenovelas. Television \& New Media, 6(4), 407-414. doi:10.1177/1527476405279956

Rubin, A. (2009). Uses and gratifications: Perspective on media effects. In J. Bryant \& M.B. Oliver (Eds.), Media effects: Advances in theory and research (3rd ed., pp. 165-184). New York, NY: Routledge.

Russell, C. A., \& Russell, D. W. (2009). Alcohol messages in prime-time television series. Journal of Consumer Affairs, 43(1), 108-128. doi:10.1111/j.17456606.2008.01129.x

Signorielli, N., \& Lears, M. (1992). Television and children's conceptions of nutrition: Unhealthy messages. Health Communication, 4(4), 245-257. doi:10.1207/ s15327027hc0404_1

Villarreal, Y. (2015, July 18). The billennial generation: How bilingual millennials are changing Spanishlanguage TV. LA Times. Retrieved from http://www. latimes.com/entertainment/envelope/cotown/la-etct-latino-millennials-univision-20150719-story.html

Violence Policy Center. (2018). Hispanic victims of lethal firearms violence in the United States. Retrieved from http://www.vpc.org/studies/hispanic18.pdf

Wilkin, H. A., Valente, T. W., Murphy, S., Cody, M. J., Huang, G., \& Beck, V. (2007). Does entertainmenteducation work with Latinos in the United States? Identification and the effects of a telenovela breast cancer storyline. Journal of Health Communication, 12(5), 455-469. doi:10.1080/10810730701438690

Yokota, F., \& Thompson, K.M. (2000). Violence in Grated animated films. JAMA, 283(20). 2716-2720. doi:10.1001/jama.283.20.271

\section{About the Authors}

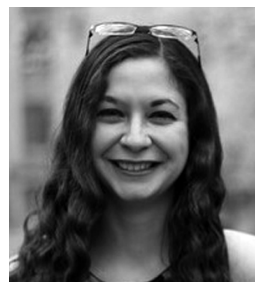

Darien Perez Ryan (BA) is a Research Project Manager for the Adolescent Health and Risk Communication Institute (AHRCl) of the Annenberg Public Policy Center at the University of Pennsylvania. Her background is in Anthropology, with a specific interest in the role of food and the meal as a form of socialization in Hispanic communities. As part of $\mathrm{AHRCI}$, Darien trains cohorts of bilingual undergraduates to content analyze popular telenovelas and other Spanish-language programming to assess health risk implications for Hispanic adolescents.

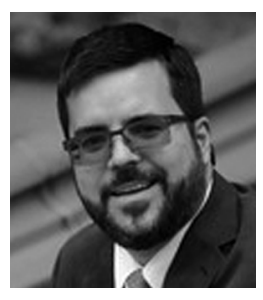

Patrick E. Jamieson (PhD) is Director of the Adolescent Health and Risk Communication Institute (AHRCl) of the Annenberg Public Policy Center at the University of Pennsylvania. He conducts research using surveys, content analyses, and statistics to study the intersection of health risk and culture of health portrayal, the exposure of such, and subsequent changes in attitudes and behavior. He coedited The Changing Portrayal of Adolescents in the Media since 1950 (Oxford University Press, 2008). 